\title{
Influence of proportion of wheat in a pasture-based diet on milk yield, methane emissions, methane yield, and ruminal protozoa of dairy cows
}

\author{
P. J. Moate, ${ }^{*}$ 니 M. H. Deighton, 당 J. Jacobs, B. E. Ribaux, G. L. Morris, M. C. Hannah, D. Mapleson, \\ M. S. Islam, W. J. Wales, and S. R. O. Williams ${ }^{\circ}$ \\ Agriculture Victoria Research, Ellinbank, Victoria 3821, Australia
}

\section{ABSTRACT}

Wheat is the most common concentrate fed to grazing dairy cows in Australia, but no studies have examined the effects of wheat proportion in a pasture-based diet on milk production and methane emissions. In this 47-d experiment, 32 Holstein dairy cows were offered 1 of 4 diets during $\mathrm{d} 1$ to 36 . Cows in each of the dietary treatment groups were individually offered no wheat (W0) or wheat at $3 \mathrm{~kg}$ of dry matter (DM)/d (W3), 6 $\mathrm{kg}$ of $\mathrm{DM} / \mathrm{d}(\mathrm{W} 6)$, or $9 \mathrm{~kg}$ of $\mathrm{DM} / \mathrm{d}(\mathrm{W} 9)$. The remainder of the diet was $2.2 \mathrm{~kg}$ of DM of concentrate mix and freshly harvested perennial ryegrass (Lolium perenne) such that all individual cows were offered a total diet of approximately $20.2 \mathrm{~kg}$ of DM/d. From d 37 to 47 the diets of cows receiving treatments W0 and W3 remained unchanged, but cows in treatments W6 and $\mathrm{W} 9$ received the W3 diet. Individual cow feed intakes, milk yields, milk compositions, and methane emissions were measured for d 31 to 35 (period 1) and d 45 to 47 (period 2). During period 1, the mean intakes of cows offered the W0, W3, W6, and W9 diets were 19.2, 20.4, 20.2 , and $19.8 \mathrm{~kg}$ of $\mathrm{DM} / \mathrm{d}$. Diet caused differences in energy-corrected milk, and means for W0, W3, W6, and W9 were $29.5,32.4,33.0$, and $32.9 \mathrm{~kg} / \mathrm{d}$, respectively. Milk fat percentage differed with respective means of 3.93, 3.94, 3.69, and 3.17. Diets also caused differences in methane emissions, with means for W0, W3, W6, and W9 of 440, 431, 414, and $319 \mathrm{~g} / \mathrm{d}$. During period 1, the cows fed the W9 diet produced less methane and had lower methane yields (g/kg of DMI) and intensities ( $\mathrm{g} / \mathrm{kg}$ of energy-corrected milk) than cows fed the W3 diet. However, in period 2 when the wheat intake of cows in the W9 treatment was reduced to the same level as in the W3 treatment, their methane emissions, yields, and intensities were similar to those offered the

Received August 29, 2019.

Accepted November 4, 2019.

*Corresponding author: peter.moate@agriculture.vic.gov.au
W3 treatment, yet protozoa numbers in ruminal fluid were still much lower than those in cows offered the W3 treatment. Our research shows that for diets based on perennial ryegrass and crushed wheat, only the diet containing more than $30 \%$ crushed wheat resulted in substantially depressed milk fat concentration and reduced methane emissions, methane yield, and methane intensity. Thus, although feeding a diet with a high proportion of wheat can cause substantial methane mitigation, it can come at the cost of depression in milk fat concentration.

Key words: greenhouse gas, dose response

\section{INTRODUCTION}

Emissions of greenhouse gases from livestock account for $14.5 \%$ of global anthropogenic emissions (Gerber et al., 2013). Clear imperatives exist for developing practical strategies that will lead to a reduction in these emissions, and the inclusion of concentrates in the diets of dairy cows could play a role in reducing emissions of methane, a potent greenhouse gas (Beauchemin et al., 2008).

When cows were fed a diet of alfalfa hay with high proportions ( $>30 \%$ on a DM basis) of wheat grain (Triticum aestivum), production responses have usually manifested as an increase in milk volume; no change in concentration of milk protein; a reduction in concentration of milk fat; an increase in yield of milk protein; and either a decrease, no change, or a slight increase in yield of milk fat (Moate et al., 2017b, 2018, 2019). Several studies have measured milk production responses to cereal grain supplements fed to grazing dairy cows (Robaina et al., 1998; Walker et al., 2001; Leddin et al., 2010) or when cows fed a basal diet of harvested pasture were also fed some cereal grains (Williams et al., 2013). However, as far as we can ascertain, no studies have been published that has reported milk production responses when cows on a basal diet of perennial ryegrass were fed different amounts of wheat as a partial substitute for the pasture. The ME concentration of wheat grain and spring-harvested perennial ryegrass 
are generally approximately 12 to 13 and 10 to 12 $\mathrm{MJ} / \mathrm{kg}$ of DM, respectively (Williams et al., 2013; Rugoho et al., 2017). Thus, substituting the pasture with grain of higher energy concentration should theoretically increase milk production. However, given previous findings when wheat was fed in an alfalfa-based diet (Moate et al., 2017b, 2018), the likely effects on milk fat concentration are less certain.

Methane yield ( $\mathrm{g} / \mathrm{kg}$ of DMI) has been reported to be lower for cows fed an alfalfa-based diet containing wheat grain than for cows fed a similar diet containing corn (Moate et al., 2017b, 2018). However, the effect has not been confirmed in lactating cows fed a perennial ryegrass-based diet.

Several dietary interventions have been shown to result in decreased methane emissions and methane yields, but the antimethanogenic effect may be transitory (Guan et al., 2006; Klop et al., 2017; Moate et al., 2018). In a frequently cited study, Weimer et al. (2010) swapped the total ruminal contents of 2 individual cows and found that rumen microbial populations took between 14 and $63 \mathrm{~d}$ to fully return to populations that resembled the pre-swap populations. The findings of Weimer et al. (2010) with respect to ruminal microbial populations and the findings of Guan et al. (2006), Klop et al. (2017), and Moate et al. (2017b) suggest that ruminal microbial populations in general and methanogen populations in particular do not respond instantaneously to dietary interventions. Therefore, we propose that a substantial carryover effect could exist against methanogenesis after cessation of feeding a diet containing a high proportion of a wheat-based concentrate. The magnitude and duration of a wheat-induced, carryover inhibitory effect against methanogenesis has not been previously researched.

Ruminal protozoa are known to harbor methanogens, and nutritional options to decrease ruminal populations of protozoa have been proposed as a strategy to mitigate enteric methane emissions (Hegarty, 1999). Previous research has reported that when cows were fed diets containing wheat instead of corn, numbers of protozoa in ruminal fluid are substantially reduced and methane emissions and yield are lower, but no evidence exists that the reduced methane emissions in wheat-fed cows are due to low numbers of protozoa in ruminal fluid. (Moate et al., 2017b, 2019).

The aim of this research was to determine the response of lactating dairy cows to increasing proportions of wheat in a perennial ryegrass-based diet. We hypothesized that (1) the yield of ECM would be positively related to the proportion of wheat in the diet; (2) methane emissions and methane yield would decrease with increasing proportion of wheat in the diet; (3) if the proportion of wheat were suddenly reduced from high to low, a carryover effect would exist on methane yield; and (4) across treatments and periods, the number of protozoa in ruminal fluid would be positively associated with methane yield.

\section{MATERIALS AND METHODS}

The experiment was conducted at Agriculture Victoria Research, Ellinbank, Victoria, Australia ( $38^{\circ} 14^{\prime} \mathrm{S}$, $145^{\circ} 56^{\prime} \mathrm{E}$ ) and was conducted in accordance with the Australian Code of Practice for the Care and Use of Animals for Scientific Purposes (National Health and Medical Research Council, 2004). Animal use was approved by the Animal Ethics Committee of the Department of Jobs, Precincts and Regions, Victoria.

\section{Cows, Diets, Feeding, and Management}

Four dietary treatments were randomized to 32 lactating, multiparous Holstein-Friesian cows. Their BW was $528 \pm 35.9 \mathrm{~kg}$ (mean $\pm \mathrm{SD}$ ), DIM was 40 \pm 12.4 , and age was $4.0 \pm 1.20 \mathrm{yr}$. Treatment groups were balanced for cow age, BW, and DIM using GenStat 18 software (VSN International, 2016), Procedure COVDESIGN according to the method of Harville (1974). The 4 dietary treatments, each of which was applied individually to 8 cows, were as follows: W0 = $0.0 \mathrm{~kg}$ of DM/d of crushed wheat grain and $\sim 18 \mathrm{~kg}$ of $\mathrm{DM} / \mathrm{d}$ of pasture; $\mathbf{W} \mathbf{3}=3.0 \mathrm{~kg}$ of $\mathrm{DM} / \mathrm{d}$ of crushed wheat grain and $\sim 15 \mathrm{~kg}$ of $\mathrm{DM} / \mathrm{d}$ of pasture; W6 = $6.0 \mathrm{~kg}$ of DM/d of crushed wheat grain and $\sim 12 \mathrm{~kg}$ of $\mathrm{DM} / \mathrm{d}$ of pasture; $\mathbf{W} \mathbf{9}=9.0 \mathrm{~kg}$ of $\mathrm{DM} / \mathrm{d}$ of crushed wheat grain and $\sim 9 \mathrm{~kg}$ of $\mathrm{DM} / \mathrm{d}$ of pasture. Pasture was predominantly perennial ryegrass (Lolium perenne). The pasture was harvested twice daily (0600 and 1400 h) at a preflowering stage and a pasture mass of approximately $2,500 \mathrm{~kg} / \mathrm{ha}$ using a front-mount mower (Novacat 356F; Pöttinger, Grieskirchen, Austria), a tractor (Arion 530; Claas, Harsewinkel, Germany), and a loader wagon (Quantum 3500P; Claas). All diets were further supplemented with $2.2 \mathrm{~kg}$ of $\mathrm{DM} /$ cow per day of a concentrate mix comprising $455 \mathrm{~g} / \mathrm{kg}$ cold-pressed canola meal, $455 \mathrm{~g} / \mathrm{kg}$ cracked corn grain, and $90 \mathrm{~g} /$ $\mathrm{kg}$ minerals. The canola meal was included in the concentrate mix to ensure that the diets met the cows' dietary requirements for protein (NRC 2001). Cows were milked twice daily at $\sim 0600$ and $\sim 1500 \mathrm{~h}$.

During the diet adjustment phase ( $\mathrm{d} 1$ to 21 ), cows offered the W3, W6, and W9 treatments were individually fed half their daily wheat allocation after each milking. The cows in the W0 group waited on a loafing pad while the other cows were eating their grain. 
When cows had finished eating their grain, all cows were moved to a paddock to graze pasture ad libitum in their respective treatment groups.

During the intensive measurement phase of the experiment (d 22 to 47), all cows were moved to the animal house after each milking, where they were individually fed half their daily grain ration first and then half their daily allocation of harvested pasture. The grain-concentrate was individually offered to cows before offering the harvested pasture. This was to mimic the pattern of feeding of supplemental concentrates that generally occurs in grazing-based dairy systems in which cows are fed concentrates during milking and then they are given access to pasture. Cows were offered their pasture once they had finished eating their wheat or after $30 \mathrm{~min}$, whichever occurred first. Cows were allowed a total of $4 \mathrm{~h}$ of access to feed in the morning (0700 to $1100 \mathrm{~h}$ ) and $4 \mathrm{~h}$ in the afternoon (1600 to $2000 \mathrm{~h}$ ), after which time cows were released from the animal house onto a wood-chip loafing pad. From d 36 onward, all cows received $2.2 \mathrm{~kg}$ of $\mathrm{DM} /$ cow per day of a concentrate mix, and cows on the W3, W6, and W9 treatments were offered $3.0 \mathrm{~kg}$ of $\mathrm{DM} / \mathrm{d}$ of crushed wheat and $\sim 15 \mathrm{~kg}$ of $\mathrm{DM} / \mathrm{d}$ of pasture.

\section{Measurements}

Samples of concentrates offered and refused were collected daily for DM determination by drying at $105^{\circ} \mathrm{C}$ for $24 \mathrm{~h}$. During the intensive measurement phase of the experiment, samples of pasture offered and refused each day were collected and DM concentration was determined each day.

Representative samples of crushed wheat, cracked corn grain, and cold-pressed canola offered were collected at each feeding, frozen, and bulked over the duration of the experiment. Representative daily samples of harvested pasture from period 1 (d 31 to 35) and from period 2 (d 45 to 47 ) were collected, frozen, and bulked over the duration of each period. Frozen samples were subsequently freeze-dried, ground to pass through a $0.5-\mathrm{mm}$ sieve, and then analyzed by Dairy One Forage Laboratory (Ithaca, NY) using their methods (Dairy One, 2019). Calculation were for CP (AOAC International, 2000; method 990.06), soluble protein (as \% of CP; Roe and Sniffen, 1990), ADF and NDF (Van Soest et al., 1991; without sodium sulfite, using an Ankom Fiber Analyzer, Ankom Technology, Fairport, NY, and with $100 \mu \mathrm{L} / 0.50 \mathrm{~g}$ of sample heat-stable $\alpha$-amylase, no. A3306, Sigma Chemical Co., St. Louis, MO), lignin (AOAC International, 2000; method 973.18), starch (Smith, 1969), ash (AOAC International, 2000; method
942.05), crude fat (ether extract; AOAC International, 2000; method 2003.05), and minerals (Na, K, Ca, Mg, $\mathrm{P}, \mathrm{Cu}$, and S; Sirois et al., 1994) and $\mathrm{Cl}$ (Cantliffe et al., 1970), with NFC, TDN, and DCAD calculated according to the procedures of Dairy One (2019). Gross energy (GE; MJ/kg of DM) was calculated based on the proportions of ash $(A)$ and fat $(F)$ in the feeds using an equation $[\mathrm{GE}(\mathrm{MJ})=38.5 \times F+19.3 \times(1-A-F)]$ we derived from data presented by Klop et al. (2017), and ME was calculated according to the NRC (2001).

Milk yields of individual cows were measured morning and afternoon for the duration of the experiment using a DeLaval ALPRO milk metering system (MM25; DeLaval International, Tumba, Sweden). During period 1, milk samples for composition analysis were collected from both the morning and afternoon milkings on every second day, and during period 2, milk samples were collected daily. Fat, protein, and lactose in milk were measured by a near-infrared milk analyzer (model 2000, Bentley Instruments, Chaska, MN). Energy-corrected milk, standardized to $4.0 \%$ fat and $3.3 \%$ protein, was calculated using the following equation (Tyrrell and Reid, 1965):

$$
\begin{gathered}
\text { ECM }(\mathrm{kg} / \mathrm{d})=[\text { milk yield }(\mathrm{kg}) \\
\times(376 \times \text { fat } \%+209 \times \text { protein } \%+948)] / 3,138 .
\end{gathered}
$$

Somatic cells were counted by a Fossomatic SC300 cell counter (Foss, Hillerød, Denmark). Milk fatty acids were determined by first extracting milk fat from fresh samples using a method based on the Rose-Gottlieb gravimetric method (International Dairy Federation, 1987). Samples of extracted milk fat were stored at $-18^{\circ} \mathrm{C}$ until they were analyzed for fatty acid composition. Following methylation with sodium methoxide (Slover and Lanza, 1979), the concentrations of fatty acid methyl esters in milk fat were determined by GC by the method described by Agnew et al. (2019). Peak identification was by retention time comparisons with fatty acid standards (189-19, 37 FAME 4:0-24:0; Sigma Chemical Co.) included every 15 samples.

\section{Methane Emissions}

Methane emissions (g/d) from each cow were sampled on d 31 to 35 (period 1) and on d 45 to 47 (period 2) using a sulfur hexafluoride $\left(\mathrm{SF}_{6}\right)$ tracer technique similar to those described by Berndt et al. (2014) and Deighton et al. (2014). In this experiment, the permeation tubes were manufactured in November 2011 by the National Institute of Water and Atmospheric Research, New Zealand, and were filled with about 2.4 
$\mathrm{g}$ of $\mathrm{SF}_{6}$. The release rate of $\mathrm{SF}_{6}$ was determined over the 4-wk period before use by storing the tubes in a dry incubator set at $39^{\circ} \mathrm{C}$ and weighing each permeation tube twice each week. The release rate of $\mathrm{SF}_{6}$ was 7.2 $\pm 0.41 \mathrm{mg} / \mathrm{d}$ (average $\pm \mathrm{SD}$ ) and ranged from 6.6 to $8.0 \mathrm{mg} / \mathrm{d}$. The permeation tubes containing $\mathrm{SF}_{6}$ were placed in the rumen of the cows per os $1 \mathrm{wk}$ before the first measurements of $\mathrm{CH}_{4}$ were performed. A feature of the $\mathrm{SF}_{6}$ technique used in this experiment is that we used orifice plate air flow regulators that collect a gas sample at a constant rate over $24 \mathrm{~h}$, and therefore, the collected gas sample reflects the daily methane emissions of each animal. This was to ensure that we did not introduce a bias into the technique, as may be the case if we had used capillary flow regulators (Deighton et al., 2014).

Stainless steel canisters with an 800-mL capacity and a sampling rate of $\sim 0.2 \mathrm{~mL} / \mathrm{min}$ were used to continuously sample eructated gases. Sentinel canisters (Williams et al., 2011) were used to sample background gases indoors $(\sim 0.8 \mathrm{~mL} / \mathrm{min}), 4$ canisters were used with one on each fence of the loafing area to sample background gases outdoors $(\sim 0.3 \mathrm{~mL} / \mathrm{min})$, and orifice plates (Lenox Laser, Glen Arm, MD) were used to control gas sampling rate (Deighton et al., 2014). Canisters were exchanged once per day. Overall background concentrations for individual cows were the time-weighted average of their individual indoor and the group outdoor concentrations (Berndt et al., 2014). Residual vacuum in all used canisters was recorded before addition of sufficient $\mathrm{N}_{2}(999.99 \mathrm{~g} / \mathrm{kg})$ to bring the remaining vacuum to $\sim 10 \mathrm{kPa}$. Cows spent approximately $8 \mathrm{~h} / \mathrm{d}$ in a wellventilated (open on 3 sides) animal house as described by Williams et al. (2011) and approximately $16 \mathrm{~h} / \mathrm{d}$ outdoors, on a wood-chip loafing pad.

Analysis of collected gas samples was done by GC (Williams et al., 2011). After analysis, the dilution by $\mathrm{N}_{2}$ was reversed mathematically to account for the physical dilution of the samples with $\mathrm{N}_{2}$ gas before analysis (Equation 1):

$$
\left[G_{\mathrm{S}}\right]=\left[\left(101-\tau_{\mathrm{f}}\right) /\left(\tau_{\mathrm{e}}-\tau_{\mathrm{s}}\right)\right] \times\left[G_{\mathrm{A}}\right],
$$

where $\left[G_{\mathrm{S}}\right]$ is the calculated concentration (ppm for $\mathrm{CH}_{4}$, ppt for $\mathrm{SF}_{6}$ ) of the gas as sampled, 101 is the average atmospheric pressure $(\mathrm{kPa}), \tau_{\mathrm{f}}(\mathrm{kPa})$ is the final vacuum in the canister after the addition of nitrogen, $\tau_{\mathrm{s}}$ $(\mathrm{kPa})$ is the vacuum in the canister after the sample is collected, $\tau_{\mathrm{e}}(\mathrm{kPa})$ is the vacuum in the evacuated canister before use, and $\left[G_{\mathrm{A}}\right]$ (ppm for $\mathrm{CH}_{4}$, ppt for $\mathrm{SF}_{6}$ ) is the gas concentration in the sample presented to the GC. Methane emissions for each cow on each day were calculated using equation 2 of Williams et al. (2011).

\section{Ruminal Fermentation and Protozoa}

A single sample of ruminal fluid $(\sim 400 \mathrm{~mL})$ was collected from each cow per os at $4 \mathrm{~h}$ after the start of feeding, on the last day of period 1 (d 33), and again on the last day of period 2 (d 47). This 4-h delay from the start of feeding was chosen to coincide with the expected nadir in ruminal pH (Greenwood et al., 2014). An oro-ruminal sampling probe, similar to the one described by Geishauser (1993), and a vacuum pump were used to collect samples (Moate et al., 2014). The $\mathrm{pH}$ of the ruminal fluid was immediately measured using a Mettler-Toledo FG2 pH meter (Schwerzenbach, Switzerland).

Ciliate protozoa were counted from a $0.5-\mathrm{mL}$ subsample of ruminal fluid transferred to a $12-\mathrm{mL}$ plastic vial; diluted with $4.5 \mathrm{~mL}$ of a stain solution (Ogimoto and Imai, 1981) containing $10 \%$ formalin, $0.8 \%$ saline, and $0.06 \%$ methyl green; and then stored at ambient conditions. Counting was done in a Mod-FuchsRosenthal counting chamber. Protozoa in the family Ophryoscolecidae were counted in the separate genera of Entodinium and of Epidinium, and protozoa from the family Isotrichidae were counted in the separate genera of Isotricha and Dasytricha.

Volatile fatty acids in ruminal fluid were measured in a 5-mL sample of ruminal fluid to which 2 drops of concentrated $\mathrm{H}_{2} \mathrm{SO}_{4}$ were added immediately before storage at $-18^{\circ} \mathrm{C}$. Analysis was by capillary GC as described in Supelco Bulletin 749D (Supelco Inc., 1975). The Dlactate in ruminal fluid was measured by a Boehringer Mannheim kit (Cat No. 11112821 035; Mannheim, Germany) on an Olympus AU400 Autoanalyzer (Tokyo, Japan) after deproteinization with perchloric acid. Ammonia- $\mathrm{N}$ concentrations were determined in $5-\mathrm{mL}$ samples of acidified ruminal fluid (Moate et al., 2017b).

\section{Statistical Analyses}

Where data were repeated measurements, they were initially averaged within each period for each cow. These, and all other data, were analyzed using mixed models (REML) in GenStat 18 software (VSN International, Hemel Hempstead, UK). For variables (DMI, milk production and composition, and methane) measured in period 1 (d 31 to 35) only, the fixed effects included a factor for wheat proportion, and the random effects were simply the experimental unit, cow. For variables with data measured in both periods 1 and 2 (d 45 to 47), the mixed model included factorial fixed effects for wheat proportion by period, and the random effects were cow and period-within-cow. Note that the protozoal data were from single spot samples 
Table 1. Composition of dietary ingredients ( $\mathrm{g} / \mathrm{kg}$ of DM unless otherwise noted)

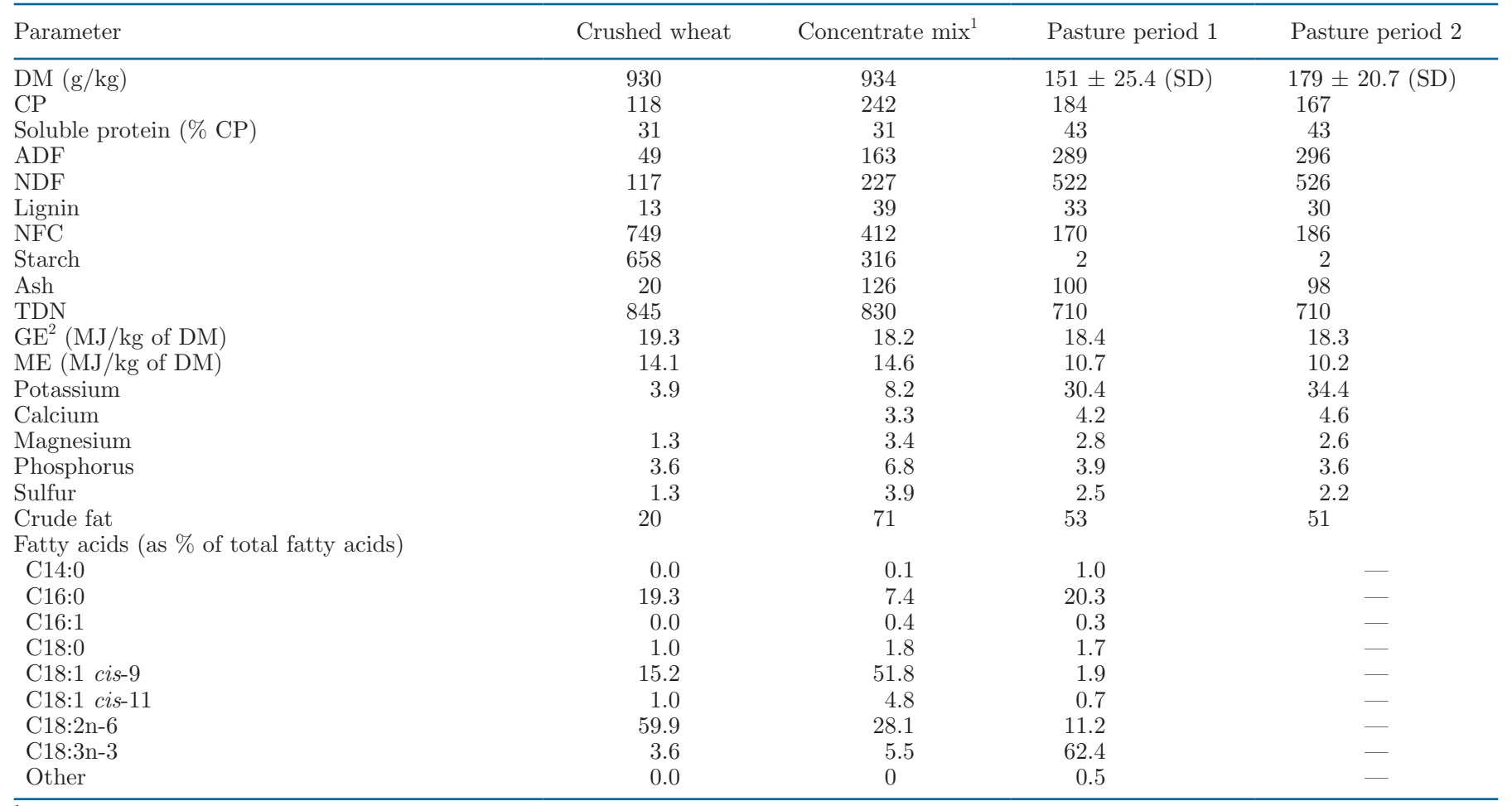

${ }^{1}$ The concentrate mix comprised (on a DM basis) $45.5 \%$ cold-pressed canola meal, $45.5 \%$ cracked corn grain, and $9.0 \%$ minerals.

${ }^{2} \mathrm{GE}=$ gross energy.

measured on the last day of period 1 (d 35) and the last day of period 2 (d 47). Linear and quadratic orthogonal polynomial contrasts for wheat proportion were applied to the estimated cow-by-period means and tested by $t$-tests derived from the variance-covariance matrix following the mixed model analysis. Similarly, pairwise comparisons between means, as well as interactions of polynomial contrasts with periods, were computed using the estimated means and their variance-covariance matrix. $F$-tests for differences between diet treatments within each period were derived by including additive fixed effects for period, wheat proportion in period 1, and for wheat proportion in period 2, and by dropping each of the wheat proportion factors in turn from the full model. The 2 factors for wheat proportion within period were defined with 5 levels: the 4 proportion treatments and a level for the other period.

All analyses included covariates DMI, age, and BW, which were used initially to balance treatment groups, and these were always the first fixed effects to be entered into the model. Distributional assumptions of normality and constant variance were examined graphically using histograms and normal quantile plots of residuals, and plots of residuals against fitted values. Somatic cell counts were transformed as $\log _{10}(\mathrm{SCC})$, and protozoa counts were transformed as $\log _{10}$ (count/ $\mathrm{mL}$ ). Total protozoa count means (geometric means) were back-transformed from this log-transformed scale.

\section{RESULTS}

\section{Feed Composition and Feed Intake}

The DM concentration of harvested pasture ranged from 93 to $208 \mathrm{~g}$ of $\mathrm{DM} / \mathrm{kg}$. This variation in DM was mainly due to day-to-day differences in weather, with instances of rain leading to decreases in DM concentration of harvested pasture. The chemical compositions of the dietary ingredients are shown in Table 1.

Cows generally ate all of the concentrate offered and at least $95 \%$ of the pasture offered. The mean DMI of pasture, crushed wheat, and concentrate for each of the dietary treatments during period 1 are shown in Table 2. Targeted total mean DMI for cows in all treatments was $20.2 \mathrm{~kg}$ of $\mathrm{DM} / \mathrm{d}$. However, day-to-day variation in the DM concentration of harvested pastures resulted in pasture offered at each feed not always matching the targeted quantities. Also, some cows in W6 and W9 dietary treatments did not consume all of the offered wheat. Mean total DMI for cows in all treatments 
Table 2. Influence of diet on feed intake, milk production, and milk composition during period 1

\begin{tabular}{|c|c|c|c|c|c|c|c|c|}
\hline Item & \multicolumn{4}{|c|}{$\operatorname{Diet}^{1}$} & SEM & \multicolumn{3}{|c|}{ Contrast ( $P$-value $)$} \\
\hline Number of cows & 8 & 8 & 8 & 8 & & & & \\
\hline Pasture & 16.9 & 15.4 & 12.2 & 8.8 & - & - & - & - \\
\hline Crushed wheat & 0 & 3.0 & 6.0 & 9.0 & - & - & - & - \\
\hline Concentrate $\operatorname{mix}^{2}$ & 2.1 & 2.1 & 2.1 & 2.1 & - & - & - & - \\
\hline Total NDF & 9.29 & 8.85 & 7.51 & 6.10 & 0.18 & $<0.001$ & $<0.001$ & $<0.001$ \\
\hline Total starch & 0.66 & 2.70 & 4.62 & 6.59 & 0.013 & $<0.001$ & $<0.001$ & 0.003 \\
\hline Total fat & 1.04 & 1.02 & 0.91 & 0.79 & 0.019 & $<0.001$ & $<0.001$ & $<0.001$ \\
\hline Gross energy intake (MJ/d) & 348 & 379 & 377 & 373 & 6.6 & $<0.001$ & 0.002 & $<0.001$ \\
\hline ME intake (MJ/d) & 210 & 237 & 244 & 251 & 3.8 & $<0.001$ & $<0.001$ & $<0.001$ \\
\hline Wheat $(\%)$ & 0 & 15.1 & 29.8 & 45.6 & 0.45 & $<0.001$ & $<0.001$ & 0.207 \\
\hline \multicolumn{9}{|l|}{ Production $(\mathrm{kg} / \mathrm{d})$} \\
\hline $\mathrm{FP}^{3}$ & 2.09 & 2.34 & 2.38 & 2.36 & 0.058 & 0.005 & 0.002 & 0.041 \\
\hline \multicolumn{9}{|l|}{ Milk composition } \\
\hline Fat $(\%)$ & 3.93 & 3.94 & 3.69 & 3.17 & 0.141 & 0.001 & $<0.001$ & 0.076 \\
\hline Protein (\%) & 3.01 & 3.16 & 3.24 & 3.24 & 0.041 & 0.001 & $<0.001$ & 0.088 \\
\hline Lactose (\%) & 5.05 & 5.08 & 5.17 & 5.31 & 0.055 & 0.006 & $<0.001$ & 0.354 \\
\hline $\log _{10} \mathrm{SCC}($ cells $/ \mu \mathrm{L})$ & 1.55 & 1.84 & 1.67 & 1.45 & 0.204 & 0.645 & 0.579 & 0.288 \\
\hline
\end{tabular}

${ }^{1} \mathrm{~W} 0=$ no wheat; $\mathrm{W} 3=3 \mathrm{~kg}$ of DM of wheat per day; W6 = $6 \mathrm{~kg}$ of DM of wheat per day; and $\mathrm{W} 9=9 \mathrm{~kg}$ of DM of wheat per day. All diets included $2.2 \mathrm{~kg}$ of DM/d of concentrate mix and freshly harvested perennial ryegrass (Lolium perenne) such that all individual cows were offered a total diet of approximately $20.2 \mathrm{~kg}$ of $\mathrm{DM} / \mathrm{d}$.

${ }^{2}$ The concentrate mix comprised (on a DM basis) $45.5 \%$ cold-pressed canola meal, $45.5 \%$ cracked corn grain, and $9.0 \%$ minerals.

${ }^{3} \mathrm{FP}=$ yield of milk fat plus milk protein.

were similar, ranging from 18.9 to $20.5 \mathrm{~kg} / \mathrm{d}$. Intakes of total $\mathrm{CP}$ and of NDF decreased as pasture intake decreased, whereas intake of starch was directly related to the intake of wheat. The average dietary concentrations of CP were 190, 180, 170, and $160 \mathrm{~g} / \mathrm{kg}$ of DMI; NDF concentrations were $492,432,372$, and $308 \mathrm{~g} / \mathrm{kg}$ of DMI; starch concentrations were $35,132,229$, and $333 \mathrm{~g} / \mathrm{kg}$ of DMI; and fat concentrations were 55,50 , 45 , and $40 \mathrm{~g} / \mathrm{kg}$ of DMI for the W0, W3, W6, and W9 diets, respectively.

\section{Milk Yield and Composition (Period 1)}

During period 1, cows consuming the W3, W6, and W9 diets all produced substantially more milk than cows consuming the W0 diet (Table 2) and a positive, linear $(P<0.001)$ relationship existed between dietary wheat proportion and milk yield. The ECM was positively, linearly $(P=0.005)$ related to wheat proportion, and a trend $(P=0.101)$ existed for a quadratic relationship between ECM and wheat proportion (Table 2). Yield of milk fat and wheat proportion had a quadratic relationship $(P=0.033)$. Yields of milk protein and milk lactose were positively, linearly $(P<$ $0.001)$ related to wheat proportion. Milk fat concentration was negatively, linearly $(P<0.001)$ related to wheat proportion, whereas concentrations of protein and lactose in milk were both positively, linearly $(P<$ 0.001) related to wheat proportion.

Mean concentrations of milk fatty acids are shown in Table 3 . Of the 25 major individual fatty acids, dietary wheat proportion and concentrations of 16 individual fatty acids had linear $(P<0.05)$ relationships, and dietary wheat proportion and concentrations of 14 individual milk fatty acids had quadratic $(P<0.05)$ relationships. Quadratic $(P<0.01)$ relationships existed between dietary wheat proportion and the concentrations of total SFA, total UFA, and total MUFA.

\section{Methane Emissions and Protozoa (Periods 1 and 2)}

During period 1, linear contrasts existed for methane emission, methane yield ( $\mathrm{g} / \mathrm{kg}$ of DMI), and methane intensity $(\mathrm{g} / \mathrm{kg}$ of ECM), all of which decreased with increasing rates of wheat. Furthermore, for methane emissions a quadratic contrast existed $(P=0.045)$, 
Table 3. Means of individual fatty acids ( $\mathrm{g} / 100 \mathrm{~g}$ of total fatty acids unless otherwise stated) and classes of fatty acids in milk fat from cows fed diets containing different concentrations of wheat during period 1

\begin{tabular}{|c|c|c|c|c|c|c|c|c|}
\hline \multirow[b]{2}{*}{ Item } & \multicolumn{4}{|c|}{ Diet $^{2}$} & \multirow[b]{2}{*}{ SEM } & \multicolumn{3}{|c|}{ Contrast ( $P$-value) } \\
\hline & W0 & W3 & W6 & W9 & & Treatment & Linear & Quadratic \\
\hline \multicolumn{9}{|l|}{ Fatty acid ${ }^{1}$} \\
\hline C4:0 & 4.08 & 3.76 & 3.84 & 2.95 & 0.196 & 0.001 & $<0.001$ & 0.096 \\
\hline C6:0 & 2.35 & 2.42 & 2.45 & 1.88 & 0.115 & 0.004 & 0.009 & 0.008 \\
\hline $\mathrm{C} 8: 0$ & 1.30 & 1.50 & 1.51 & 1.21 & 0.074 & 0.020 & 0.439 & 0.003 \\
\hline $\mathrm{C} 12: 0$ & 3.01 & 3.93 & 4.05 & 3.92 & 0.205 & 0.005 & 0.003 & 0.025 \\
\hline C14:0 & 11.5 & 12.2 & 13.0 & 12.6 & 0.377 & 0.044 & 0.016 & 0.153 \\
\hline C14:1 & 0.93 & 0.76 & 0.85 & 1.26 & 0.089 & 0.003 & 0.007 & 0.004 \\
\hline iso $\mathrm{C} 15: 0$ & 0.23 & 0.23 & 0.20 & 0.19 & 0.010 & 0.019 & 0.003 & 0.924 \\
\hline anteiso $\mathrm{C} 15: 0$ & 0.51 & 0.51 & 0.45 & 0.47 & 0.031 & 0.353 & 0.176 & 0.588 \\
\hline C15:0 & 0.94 & 0.94 & 1.04 & 1.66 & 0.129 & $<0.001$ & $<0.001$ & 0.020 \\
\hline C16:0 & 29.5 & 29.5 & 29.2 & 29.1 & 1.03 & 0.987 & 0.726 & 0.986 \\
\hline C18:1 trans -9 & 0.27 & 0.28 & 0.24 & 0.25 & 0.014 & 0.199 & 0.118 & 0.816 \\
\hline $\mathrm{C} 18: 1$ trans -10 & 0.21 & 0.23 & 0.29 & 0.70 & 0.057 & $<0.001$ & $<0.001$ & 0.002 \\
\hline C18:1 cis-9 & 19.3 & 17.7 & 18.0 & 20.3 & 0.716 & 0.060 & 0.277 & 0.013 \\
\hline $\mathrm{C} 18: 1$ cis -11 & 0.35 & 0.40 & 0.49 & 0.76 & 0.040 & $<0.001$ & $<0.001$ & 0.009 \\
\hline $\mathrm{C} 18: 2 \mathrm{n}-6$ cis & 0.86 & 0.95 & 1.14 & 1.53 & 0.062 & $<0.001$ & $<0.001$ & 0.022 \\
\hline $\mathrm{C} 18: 2$ cis- 9, trans -11 & 0.87 & 0.82 & 0.73 & 0.60 & 0.113 & 0.327 & 0.073 & 0.751 \\
\hline C18:3n-3 & 0.56 & 0.49 & 0.41 & 0.38 & 0.029 & $<0.001$ & $<0.001$ & 0.474 \\
\hline C20:0 & 0.11 & 0.12 & 0.11 & 0.08 & 0.005 & $<0.001$ & $<0.001$ & 0.003 \\
\hline Total C18 & 35.8 & 33.8 & 32.7 & 32.6 & 1.15 & 0.177 & 0.040 & 0.428 \\
\hline Total de novo ${ }^{3}$ & 42.7 & 44.8 & 45.9 & 44.2 & 0.948 & 0.134 & 0.181 & 0.055 \\
\hline Total SFA & 68.4 & 70.3 & 70.0 & 65.4 & 1.07 & 0.011 & 0.047 & 0.005 \\
\hline Total UFA & 31.6 & 29.7 & 30.0 & 34.6 & 1.07 & 0.011 & 0.047 & 0.005 \\
\hline Total MUFA & 25.2 & 23.5 & 23.8 & 27.1 & 0.86 & 0.024 & 0.104 & 0.008 \\
\hline Total PUFA & 2.29 & 2.26 & 2.28 & 2.51 & 0.150 & 0.570 & 0.290 & 0.375 \\
\hline
\end{tabular}

${ }^{1}$ Expressed as number of carbon atoms.

${ }^{2} \mathrm{~W} 0=$ no wheat; $\mathrm{W} 3=3 \mathrm{~kg}$ of DM of wheat per day; W6 $=6 \mathrm{~kg}$ of DM of wheat per day; and W9 = $9 \mathrm{~kg}$ of DM of wheat per day. All diets included $2.2 \mathrm{~kg}$ of DM/d of concentrate mix and freshly harvested perennial ryegrass (Lolium perenne) such that all individual cows were offered a total diet of approximately $20.2 \mathrm{~kg}$ of $\mathrm{DM} / \mathrm{d}$.

${ }^{3}$ Total de novo $=\operatorname{sum}(\mathrm{C} 4.0$ to $\mathrm{C} 15: 0)+0.5 \times(\mathrm{C} 16: 0)$.

with no difference in methane emission for W0, W3, and W6, but methane emissions for W9 were less than those for the other treatments. For each of the methane variables, both linear and quadratic contrasts interacted with period $(P<0.01)$. For each methane variable, the rate of decline was greater in period 1 than in period 2 (Table 4). In particular, between-period differences were substantial $(P<0.001)$ in methane emission, yield, and intensity for cows offered the W9 diet.

During period 1, the total number of protozoa in ruminal fluid and the wheat proportion had a negative linear relationship $(P<0.001)$. This mainly occurred because of the negative relationships between the wheat proportion and the numbers of Entodinium spp. and Dasytricha spp. During period 2, cows in treatment W9 had smaller $(P=0.002)$ numbers of Entodinium spp. and smaller $(P=0.005)$ numbers of total protozoa than cows offered the other treatments. For cows offered treatment W9, despite substantial $(P<0.001)$ between-period differences in methane emission, yield, and intensity, periods did not differ $(P>0.05)$ in the total count of protozoa, and differences between periods in the counts of Entodinium spp. and Isotricha spp. were small.

\section{Rumen Fermentation (Period 1)}

The $\mathrm{pH}$ in ruminal fluid was not influenced by the wheat proportion, but a negative linear relationship $(P$ $<0.001$ ) existed between the wheat proportion and the $\mathrm{NH}_{3}$ concentration in ruminal fluid (Table 5). Wheat proportion did not influence the total concentration of VFA in ruminal fluid, but generally linear and quadratic relationships existed between wheat proportion 
and the molar proportions of most of the individual VFA. Wheat proportion and the acetate-to-propionate ratio in ruminal fluid had a negative linear relationship $(P<0.001)$. A positive linear relationship $(P<0.001)$ existed between the proportion of wheat in the diet and the concentration of D-lactate in ruminal fluid.

\section{DISCUSSION}

The dairy industries in Australia, Chile, Ireland, and New Zealand are based on the grazing of perennial rye- grass pastures. To date, much research has been published on strategies for methane mitigation from dairy cows fed TMR diets, but much less research has targeted methane mitigation in dairy systems based on grazing of pastures, especially perennial ryegrass (Martin et al., 2010; Knapp et al., 2014). The current research focused on milk production and methane responses when dairy cows were offered a perennial ryegrass-dominant diet substituted with different amounts of crushed wheat. This area of research is particularly relevant to dairy farmers in Australia, because Australia is one of the

Table 4. Influence of diet on feed intake and $\mathrm{CH}_{4}$ emissions of cows during the last $4 \mathrm{~d}$ of period 1 and during the last $2 \mathrm{~d}$ of period 2

\begin{tabular}{|c|c|c|c|c|c|c|c|c|}
\hline \multirow[b]{2}{*}{ Item } & \multicolumn{4}{|c|}{$\operatorname{Diet}^{1}$} & \multirow[b]{2}{*}{ SEM } & \multicolumn{3}{|c|}{ Contrast ( $P$-value) } \\
\hline & W0 & W3 & W6 & W9 & & Treatment & Linear & Quadratic \\
\hline \multicolumn{9}{|l|}{ Period 1} \\
\hline Number of cows ${ }^{2}$ & 8 & 7 & 8 & 8 & & & & \\
\hline \multicolumn{9}{|l|}{ Feed intake $(\mathrm{kg} / \mathrm{d})$} \\
\hline Pasture & 16.9 & 15.6 & 12.2 & 8.8 & & & & \\
\hline Crushed wheat & 0 & 2.9 & 6.0 & 9.0 & & & & \\
\hline Concentrate $\operatorname{mix}^{3}$ & 2.1 & 2.1 & 2.1 & 2.1 & & & & \\
\hline Total DMI & 19.0 & 20.6 & 20.3 & 19.9 & & & & \\
\hline $\mathrm{CH}_{4}(\mathrm{~g} / \mathrm{d})$ & 440 & 431 & 414 & 319 & 20.3 & $<0.001$ & $<0.001$ & 0.045 \\
\hline $\mathrm{CH}_{4}(\mathrm{~g} / \mathrm{kg}$ of DMI $)$ & 23.6 & 21.3 & 21.1 & 16.4 & 0.91 & $<0.001$ & $<0.001$ & 0.196 \\
\hline $\mathrm{CH}_{4}(\mathrm{~g} / \mathrm{kg}$ of $\mathrm{ECM})$ & 15.3 & 13.5 & 12.5 & 9.0 & 0.99 & $<0.001$ & $<0.001$ & 0.308 \\
\hline $\mathrm{CH}_{4}\left(\%\right.$ of $\left.\mathrm{GEI}^{4}\right)$ & 7.03 & 6.28 & 6.13 & 4.82 & 0.27 & $<0.001$ & $<0.001$ & 0.201 \\
\hline \multicolumn{9}{|c|}{ Protozoa $^{5}\left[\log _{10}(\right.$ count $\left./ \mathrm{mL})\right]$} \\
\hline Entodinium spp. & 5.79 & 5.73 & 5.22 & 4.64 & 0.264 & 0.011 & 0.002 & 0.337 \\
\hline Epidinium spp. & 4.37 & 4.08 & 4.11 & 3.75 & 0.143 & 0.053 & 0.011 & 0.794 \\
\hline Isotricha spp. & 4.09 & 4.04 & 4.10 & 3.89 & 0.104 & 0.373 & 0.206 & 0.416 \\
\hline Dasytricha spp. & 4.50 & 4.46 & 4.09 & 3.87 & 0.130 & 0.002 & $<0.001$ & 0.496 \\
\hline Other & 3.96 & 3.88 & 3.80 & 3.84 & 0.058 & 0.260 & 0.103 & 0.286 \\
\hline Total & 5.86 & 5.81 & 5.31 & 4.70 & 0.245 & 0.005 & $<0.001$ & 0.268 \\
\hline Total (count/ $\mu \mathrm{L})$ & 710 & 644 & 196 & 45 & - & - & - & - \\
\hline \multicolumn{9}{|l|}{ Period 2} \\
\hline \multicolumn{9}{|l|}{ Feed intake $(\mathrm{kg} / \mathrm{d})$} \\
\hline Pasture & 17.0 & 15.8 & 14.9 & 14.5 & & & & \\
\hline Crushed wheat & 0 & 3.0 & 3.0 & 3.0 & & & & \\
\hline Concentrate mix & 2.1 & 2.1 & 2.1 & 2.1 & & & & \\
\hline Total DMI & 19.1 & 20.9 & 20.0 & 19.6 & & & & \\
\hline $\mathrm{CH}_{4}(\mathrm{~g} / \mathrm{d})$ & 462 & 442 & 442 & 422 & 20.3 & 0.578 & 0.191 & 0.996 \\
\hline $\mathrm{CH}_{4}(\mathrm{~g} / \mathrm{kg}$ of $\mathrm{DMI})$ & 25.0 & 21.2 & 22.3 & 21.7 & 0.91 & 0.042 & 0.039 & 0.100 \\
\hline $\mathrm{CH}_{4}(\mathrm{~g} / \mathrm{kg}$ of $\mathrm{ECM})$ & 17.0 & 14.9 & 14.5 & 13.4 & 0.99 & 0.023 & 0.004 & 0.550 \\
\hline $\mathrm{CH}_{4}(\%$ of $\mathrm{GEI})$ & 7.37 & 6.40 & 6.70 & 6.51 & 0.27 & 0.040 & 0.036 & 0.121 \\
\hline \multicolumn{9}{|c|}{ Protozoa $^{6}\left[\log _{10}(\right.$ count $\left./ \mathrm{mL})\right]$} \\
\hline Entodinium spp. & 5.85 & 5.43 & 5.08 & 4.32 & 0.264 & 0.002 & $<0.001$ & 0.522 \\
\hline Epidinium spp. & 4.19 & 3.72 & 3.92 & 3.78 & 0.143 & 0.187 & 0.141 & 0.298 \\
\hline Isotricha spp. & 3.82 & 4.08 & 3.97 & 4.12 & 0.094 & 0.174 & 0.078 & 0.614 \\
\hline Dasytricha spp. & 4.53 & 4.17 & 4.13 & 4.04 & 0.130 & 0.056 & 0.013 & 0.309 \\
\hline Other & 3.79 & 3.78 & 3.78 & 3.75 & 0.058 & 0.952 & 0.619 & 0.850 \\
\hline Total & 5.89 & 5.46 & 5.13 & 4.60 & 0.245 & 0.005 & $<0.001$ & 0.862 \\
\hline Total $($ count $/ \mu \mathrm{L})$ & 778 & 279 & 129 & 34 & - & - & - & - \\
\hline
\end{tabular}

${ }^{1} \mathrm{~W} 0=$ no wheat; $\mathrm{W} 3=3 \mathrm{~kg}$ of DM of wheat per day; W6 = $6 \mathrm{~kg}$ of DM of wheat per day; and W9 = $9 \mathrm{~kg}$ of DM of wheat per day. All diets included $2.2 \mathrm{~kg}$ of DM/d of concentrate mix and freshly harvested perennial ryegrass (Lolium perenne) such that all individual cows were offered a total diet of approximately $20.2 \mathrm{~kg}$ of DM/d. In period 2, treatments W3, W6, and W9 all received $3 \mathrm{~kg}$ of DM of wheat per day.

${ }^{2}$ Equipment failure prevented methane measurements on one cow in treatment W3, and this is why average DMI for this treatment group differs from that shown in Table 2.

${ }^{3}$ The concentrate mix comprised (on a DM basis) $45.5 \%$ cold-pressed canola meal, $45.5 \%$ cracked corn grain, and $9.0 \%$ minerals.

${ }^{4} \mathrm{GEI}=$ gross energy intake.

${ }^{5}$ Ruminal fluid was collected $4 \mathrm{~h}$ after the start of feeding on the last day of period 1.

${ }^{6}$ Ruminal fluid was collected $4 \mathrm{~h}$ after the start of feeding on the last day of period 2 . 
Table 5. Rumen $\mathrm{pH}^{1}$ and fermentation characteristics in dairy cows fed diets based on perennial ryegrass with different proportions of wheat during period 1

\begin{tabular}{|c|c|c|c|c|c|c|c|c|}
\hline \multirow[b]{2}{*}{ Item } & \multicolumn{4}{|c|}{ Diet $^{2}$} & \multirow[b]{2}{*}{ SEM } & \multicolumn{3}{|c|}{ Contrast ( $P$-value) } \\
\hline & W0 & W3 & W6 & W9 & & Treatment & Linear & Quadratic \\
\hline $\mathrm{pH}$ & 6.54 & 6.51 & 6.66 & 6.30 & 0.089 & 0.051 & 0.156 & 0.068 \\
\hline $\mathrm{NH}_{3}(\mathrm{mg} / \mathrm{L})$ & 198 & 137 & 123 & 55 & 13.5 & $<0.001$ & $<0.001$ & 0.564 \\
\hline Total VFA $(\mathrm{m} M)$ & 94 & 91 & 91 & 100 & 6.5 & 0.677 & 0.493 & 0.318 \\
\hline \multicolumn{9}{|c|}{ Individual VFA (mol/100 mol) } \\
\hline iso-Butyric acid & 0.91 & 0.91 & 0.89 & 0.71 & 0.043 & 0.005 & 0.002 & 0.048 \\
\hline$n$-Butyric acid & 11.2 & 11.7 & 11.5 & 8.2 & 0.644 & 0.001 & 0.002 & 0.006 \\
\hline iso-Valeric acid & 1.39 & 1.51 & 1.54 & 1.23 & 0.091 & 0.083 & 0.254 & 0.024 \\
\hline$n$-Valeric acid & 1.05 & 0.95 & 1.26 & 2.00 & 0.127 & $<0.001$ & $<0.001$ & 0.003 \\
\hline Caproic acid & 0.07 & 0.02 & 0.09 & 0.35 & 0.046 & $<0.001$ & $<0.001$ & 0.003 \\
\hline $\mathrm{A}: \mathrm{P}$ ratio & 3.15 & 3.13 & 2.99 & 1.73 & 0.194 & $<0.001$ & $<0.001$ & 0.003 \\
\hline D-Lactate $(\mu M)$ & 11.9 & 26.1 & 27.4 & 38.6 & 4.83 & 0.004 & $<0.001$ & 0.932 \\
\hline
\end{tabular}

${ }^{1}$ Ruminal fluid was collected $4 \mathrm{~h}$ after the start of feeding on the last day of period 1.

${ }^{2} \mathrm{~W} 0=$ no wheat; $\mathrm{W} 3=3 \mathrm{~kg}$ of DM of wheat per day; $\mathrm{W} 6=6 \mathrm{~kg}$ of DM of wheat per day; and $\mathrm{W} 9=9 \mathrm{~kg}$ of DM of wheat per day. All diets included $2.2 \mathrm{~kg}$ of DM/d of concentrate mix and freshly harvested perennial ryegrass (Lolium perenne) such that all individual cows were offered a total diet of approximately $20.2 \mathrm{~kg}$ of $\mathrm{DM} / \mathrm{d}$.

few countries where the dairy industry is based on grazing of perennial ryegrass-dominant pastures with the addition of substantial amounts of grain, principally wheat, fed either as a supplement or a substitute for pasture (Moate et al., 2016). Wheat is generally the supplement of choice because it economically provides $\mathrm{ME}$, the nutrient which is often limiting in pasturebased diets (Kolver and Muller, 1998).

The milk production and methane responses of cows offered basal diets of alfalfa hay and a grain component of either crushed corn grain or crushed wheat grain have been reported previously (Moate et al., 2017b, $2018,2019)$. The grain portion of the diet in those experiments always constituted between 43.5 and $47.6 \%$ of DMI. Our experiment differs from those of Moate et al. $(2017 b, 2018,2019)$ in that the basal diet was composed of freshly harvested perennial ryegrass, and the wheat component of the diet was offered at 0,15 , 30 , or $45 \%$ of total DMI. Indeed, as far as we can ascertain, this is the first experiment to document milk production and methane responses to a pasture-based diet containing different proportions of wheat.

Yield of ECM increased linearly with increasing proportion of wheat in the diet of dairy cows, leading us to accept our first hypothesis. However, compared with the W0 diet, the W9 diet depressed milk fat concentration. This negative effect on milk fat was offset by increases in protein and lactose concentrations and an increase in milk volume, resulting in net increases in ECM. Depression of milk fat concentration has also been observed when cows grazing at pasture were fed a supplement of wheat (Stockdale, 2004) and when wheat and corn feeding were compared (Moate et al., 2017b, 2018, 2019). Increases in ECM with increasing proportions of wheat in the diet have been reported for dairy cows fed a basal diet of Persian clover (Leddin et al., 2010) or ryegrass (Robaina et al., 1998; Wales et al., 2009; Auldist et al., 2013). Production of fat plus protein appeared to plateau at $6 \mathrm{~kg}$ of $\mathrm{DM}$ of wheat per day, and this is close to the average value of $5.7 \mathrm{~kg}$ of $\mathrm{DM} / \mathrm{d}$ of concentrate fed to grazing dairy cows in Australia (Dharma et al., 2012).

The magnitude of milk yield responses from grazing dairy cows fed a concentrate feed supplement may not always reflect the ME supplied by the grain because the cows usually eat less pasture when they are offered grain (pasture substitution), and excreting the excess nitrogen often associated with pasture diets has an energy cost. The milk responses from our cows given the W9 diet were $0.7 \mathrm{~kg}$ of milk $/ \mathrm{kg}$ of DM of wheat and 0.4 $\mathrm{kg}$ of ECM $/ \mathrm{kg}$ of DM of wheat. This response is similar to the $0.75 \mathrm{~kg}$ of milk $/ \mathrm{kg}$ of DM of concentrate reported for grazing cows given $5 \mathrm{~kg}$ of DM of concentrate per day (Robaina et al., 1998). This is expected given our substitution rate of 1 and the calculated substitution rate of 0.98 in the grazing experiment of Robaina et al. (1998). The energy cost to excrete excess urea produced by cows on pasture-only diets is $30 \mathrm{~kJ}$ of ME/g of nitrogen. This is associated with the high CP intakes from pasture-only diets or pasture diets supplemented with a low amount of cereal grain (Tyrrell et al., 1970). We note that the overall dietary $\mathrm{CP}$ concentrations in our W0 and W3 diets were 190 and $180 \mathrm{~g} / \mathrm{kg}$ of DM, and these concentrations are above requirements rec- 
ommended by the NRC (2001). Thus, milk production of the cows fed the W0 and W3 diets was affected by the energy cost of excreting excess nitrogen, whereas those fed the W9 diet required less energy to excrete nitrogen due to the substitution of pasture by grain.

Differences between the concentrations of individual fatty acids in the milk of cows offered the W0 and W9 diets were not large. This is despite 16 individual milk fatty acids being linearly related to the proportion of wheat in the diet in period 1 . The concentrations of all the individual fatty acids measured in this experiment were within previously reported ranges (Stockdale et al., 2003; Moate et al., 2007). Furthermore, our findings on the trends in individual milk fatty acids with increasing proportions of wheat in the diet of dairy cows are similar to the findings of Wales et al. (2009), who measured milk fatty acids from cows that grazed perennial ryegrass pasture and fed $0,2.6$, or $4.9 \mathrm{~kg}$ of $\mathrm{DM} / \mathrm{d}$ of a concentrate supplement composed of $65 \%$ rolled barley grain (Hordeum vulgare), 35\% steam-flaked corn (Zea mays), and 5\% molasses. The perennial ryegrass used in our experiment had a greater concentration of crude fat than did wheat, with linolenic acid (C18:3), an n-3 fatty acid regarded as being beneficial for health (Haug et al., 2007), constituting the majority of the fatty acids in the perennial ryegrass. Furthermore, C18:3 in milk fat is a preformed fatty acid that originates from the diet (Moate et al., 2007). Thus, in our experiment the proportion of C18:3 in milk fat was linearly, positively related to the proportion of grass in the diet. This relationship was also reported by Couvreur et al. (2006). Total SFA in milk were positively related to the proportion of grass in the diet in our work, but Couvreur et al. (2006) reported the opposite relationship. Both C15:0 and C17:0 were negatively, linearly related to the proportion of grass in the diet in our experiment, but again Couvreur et al. (2006) reported the opposite. This contrast in results may be due to differences in the diets used. We used combinations of grass and crushed wheat, whereas Couvreur et al. (2006) fed their cows combinations of grass and corn silage. Regardless of the reason for these differences, the fact that the direction of the correlations between the proportion of grass in the diet and the concentrations of either C15:0 or C17:0 was different in our experiment compared with that in the experiment of Couvreur et al. (2006) suggests that the concentrations of $\mathrm{C} 15: 0$ and $\mathrm{C} 17: 0$ in milk could not be used as reliable predictors of the proportion of grass in a diet. Overall, our findings in milk fatty acids from cows fed pasture supplemented with wheat are similar to previously reported findings when cows were fed alfalfa hay and wheat (Moate et al., 2017b, 2018, 2019).
The concentration of C18:1 trans-10 in milk fat was negatively associated with the concentration of milk fat and with methane production and methane yield. This reflects previously reported results (Moate et al., 2017b, 2018, 2019). Concentrations of C18:1 trans-10, along with $\mathrm{C} 15: 0$ and $\mathrm{C} 17: 0$, have been identified as being indicators of SARA (Fievez et al., 2012). All 3 of these fatty acids were linearly related to the proportion of wheat in the diet, suggesting that our cows may have experienced SARA for some of the time. However, this was not reflected in the measured values of ruminal fluid $\mathrm{pH}$ measured at the expected time of $\mathrm{pH}$ nadir.

Methane emission and yield decreased with increasing proportion of wheat in the diet, and we therefore accept our second hypothesis. The effect of wheat on methane emission was quadratic with no difference between W3 and W6 but with substantially less methane for the W9 treatment. This finding is similar to the finding of Sauvant et al. (2011), who found that methane emissions only declined when concentrates constituted more than approximately $50 \%$ of the diet. The methane yields for cows consuming the W0, W3, and W6 diets were all slightly greater than the $20.5 \mathrm{~g} / \mathrm{kg}$ of DM reported by Charmley et al. (2016) for beef and dairy cows consuming diets containing less than $30 \%$ concentrate. However, during period 1 , the methane emissions, methane yield, and methane intensity of cows fed the W9 diet were similar in magnitude to those in previous experiments when cows were offered diets with a similar proportion of wheat (Moate et al., 2017b, 2018, 2019). The methane emissions and yields from cows fed the W3 and W6 diets were not statistically different from each other nor from those of cows given the W0 diet. However, methane emission declined linearly and quadratically and methane yield declined linearly with increasing proportions of wheat in the diet. In contrast, Sauvant et al. (2011) reported a quadratic relationship between the proportion of concentrate in the diet and methane yield expressed as $\mathrm{g}$ of $\mathrm{CH}_{4} / \mathrm{kg}$ of digestible $\mathrm{OM}$, with a maximum when concentrate (mainly corn grain) constituted $23 \%$ of DMI. The difference in responses observed in our research and that of Sauvant et al. (2011) is likely due to the different basal diets (freshly harvested perennial ryegrass vs. alfalfa hay), different grain types (wheat grain vs. corn grain), and different range of concentrate inclusion (11 to $52 \%$ vs. 0 to $90 \%)$.

No carryover effect existed on methane yield when the amount of wheat was suddenly reduced from high to low; therefore, we reject our third hypothesis. Although the cows offered the W9 treatment were receiving a high proportion of grain, their methane yield was less than that of the cows on the low grain treatments. 
However, $12 \mathrm{~d}$ after the cows on the W9 treatment had their grain reduced to a level the same as for the W3 treatment, their methane yield was not different from that of those cows on the W3 treatment. Although we were able to find reports describing the transience of methane responses to some dietary methane mitigants, we were unable to find any reports describing the carryover effects once a dietary treatment was removed. We had considered the possibility that feeding high amounts of wheat intermittently instead of continuously might be a cost-effective strategy to reduce methane emissions from dairy cows as a smaller amount of expensive wheat would need to be fed. However, as no carryover effect existed on methane mitigation, an intermittent wheat-feeding strategy is unlikely to be a practical strategy for this purpose.

The number of protozoa in ruminal fluid was not associated with methane yield; therefore, we reject our fourth hypothesis. During period 1, negative, linear associations existed between the dietary wheat proportion and the numbers of Entodinium spp., Dasytricha spp., and total protozoa in ruminal fluid. Furthermore, for cows offered the W9 diet, the numbers of total protozoal in ruminal fluid were approximately only $5 \%$ of the number of total protozoa in the ruminal fluid of cows offered the W0 diet. The effect in period 1 of the W9 (high-wheat) diet on protozoal numbers, and concomitantly methane yield, is consistent with previous reports (Moate et al., 2017b, 2019). Ruminal protozoa have been reported to have a close association with many methanogens (Chagan and Ushida, 2004), with some researchers claiming a causal link between methane emissions and protozoa numbers (Kreuzer et al., 1986; Guan et al., 2006). However, in our experiment methane emissions, methane yield, and methane intensity for cows in treatment W9 were all greater during period 2 compared with period 1 , and the numbers of total protozoa in ruminal fluid of cows in the W9 treatment were similar in each period. Similarly, Animut et al. (2008) found large differences between treatments in numbers of ruminal protozoa but no differences in methane yields. This suggests the numbers of protozoa in ruminal fluid and methane parameters are not always linked. We acknowledge that our cows may not have fully adapted to the change in diet before measurements were made in period 2 and that ruminal protozoa were counted on just 2 occasions in a small sample of ruminal fluid. However, our data show that methane emission, yield, and intensity had all reverted to relatively normal levels even if milk production and ruminal parameters had not. Thus, even though our cows may not have fully adapted by the time of mea- surement in period 2, clearly, no link exists between methane and ruminal protozoa in our experiment. We suggest that future studies of the relationship between methane production rates and the dynamic changes that occur in ruminal protozoal populations collect more frequent samples to allow clearer elucidation of this phenomenon.

The $\mathrm{pH}$ of ruminal fluid was not substantially influenced by the different dietary treatments. Furthermore, diet $\mathrm{W} 9$ resulted in a ruminal fluid $\mathrm{pH}$ of 6.3 . This is in contrast to previous research using similar methods and similar diets where ruminal fluid $\mathrm{pH}$ values in the range 5.6 to 5.9 were reported (Moate et al., 2018, 2019). In our research, proportion of wheat in the diet and concentration of ammonia in ruminal fluid had a strong negative relationship, and we surmise that this was related to the $\mathrm{CP}$ concentration in the diet, which was also negatively related to the amount of wheat in the diet. Many articles in the scientific literature have discussed the influence of forage-to-concentrate ratio of dairy cow diets on ruminal fermentation, with emphasis on $\mathrm{pH}$ of ruminal fluid and concentrations of ammonia, total VFA, and individual fatty acids (Lana et al., 1998; Yang et al., 2001). These studies have often focused on identifying appropriate forage-to-concentrate ratios to avoid ruminal acidosis and low milk fat syndrome (Plaizier et al., 2008). However, most of this previous research was not focused on pasture-based diets, or diets containing substantial proportions of wheat, and recommendations regarding minimum dietary NDF requirements have mostly been based on diets containing alfalfa or corn silage as the predominant forage and ground corn as the predominant starch source (NRC, 2001). In our research, even when wheat was included at $30 \%$ in a perennial ryegrass-based diet, the dietary NDF concentration was $372 \mathrm{~g} / \mathrm{kg}$ of DM and milk fat concentrations was not decreased relative to the pasture-based diet containing no wheat.

The concentration of total VFA in ruminal fluid was not affected by the different dietary treatments. However, the proportion of wheat in the diet and the molar proportion of propionate had a positive linear relationship, and the proportion of wheat in the diet and the molar proportion of acetate as well as the acetate-to-propionate ratio had negative relationships. The acetate-to-propionate ratio is generally positively related to the milk fat concentration and to methane yield (Mohammed et al., 2004; Moate et al., 2018). In our research, only the W9 diet was associated with a low acetate-to-propionate ratio and low milk fat concentration. In light of the findings of our research, it is not surprising that in Australia, grazing dairy cows 
are fed on average approximately $1.7 \mathrm{t}$ of $\mathrm{DM}$ of concentrates per year (i.e., approximately $6 \mathrm{~kg}$ of $\mathrm{DM} / \mathrm{d}$; Dharma et al., 2012; Moate et al., 2016).

It has been suggested that diets containing a high proportion of grain (wheat or corn) should not be fed to ruminants on ethical grounds because cereals could be fed directly to humans or monogastric animals (Doreau et al., 2014). However, Australian dairy cows generally consume less than $10 \%$ of the wheat grown in Australia, and most of this is classified as unsuitable for human consumption due to weather damage, sprouting, or presence of foreign materials (Moate et al., 2016). Furthermore, in terms of producing food for humans, it is more efficient to feed grain to dairy cows and produce milk than it is to use it to produce chicken or pig meats (Wilkinson, 2011). Thus, the feeding of feed-quality wheat to dairy cows is an efficient way to produce high-quality food for humans.

\section{CONCLUSIONS}

This experiment has quantified for the first time milk production and methane responses from perennial ryegrass pasture-based diets containing different proportions of crushed wheat. The important finding from this research was that for diets based on perennial ryegrass and crushed wheat, only the diet containing more than $30 \%$ crushed wheat resulted in substantially depressed milk fat concentration and reduced methane emissions, methane yield, and methane intensity. Thus, although feeding a diet with a high proportion of wheat can cause substantial methane mitigation, it can come at the cost of depression in milk fat concentration.

\section{ACKNOWLEDGMENTS}

This investigation was funded by Agriculture Victoria Research, Dairy Australia, Meat and Livestock Australia, and the Australian Government Department of Agriculture, Fisheries and Forestry under its Australia's Farming Future Climate Change Research Program. The authors have no conflicts of interest.

\section{REFERENCES}

Agnew, M. P., C. R. Craigie, G. Weralupitiya, M. M. Reis, P. L. Johnson, and M. G. Reis. 2019. Comprehensive evaluation of parameters affecting one-step method for quantitative analysis of fatty acids in meat. Metabolites 9:189. https://doi.org/10.3390/ metabo9090189.

Animut, G., R. Puchala, A. L. Goetsch, A. K. Patra, T. Sahlu, V. H. Varel, and J. Wells. 2008. Methane emission by goats consuming different sources of condensed tannins. Anim. Feed Sci. Technol. 144:228-241. https://doi.org/10.1016/j.anifeedsci.2007.10.015.

AOAC International. 2000. Official Methods of Analysis of AOAC International. 17th ed. AOAC Int., Arlington, VA.
Auldist, M. J., L. C. Marett, J. S. Greenwood, M. Hannah, J. L. Jacobs, and W. J. Wales. 2013. Effects of different strategies for feeding supplements on milk production responses in cows grazing a restricted pasture allowance. J. Dairy Sci. 96:1218-1231. https:/ /doi.org/10.3168/jds.2012-6079.

Beauchemin, K. A., M. Kreuzer, F. O'Mara, and T. A. McAllister. 2008. Nutritional management for enteric methane abatement: A review. Aust. J. Exp. Agric. 48:21-27. https://doi.org/10.1071/ EA07199.

Berndt, A., T. M. Boland, M. H. Deighton, J. I. Gere, C. Grainger, R. S. Hegarty, A. D. Iwaasa, J. P. Koolaard, K. R. Lassey, D. Luo, R. J. Martin, C. Martin, P. J. Moate, G. Molano, C. Pinares-Patiño, B. E. Ribaux, N. M. Swainson, G. C. Waghorn, and S. R. O. Williams. 2014. Guidelines for Use of Sulphur Hexafluoride $\left(\mathrm{SF}_{6}\right)$ Tracer Technique to Measure Enteric Methane Emissions from Ruminants. Page 166. M. G. Lambert, ed. New Zealand Agric. Greenhouse Gas Res. Cent., Palmerston North, New Zealand.

Cantliffe, D. J., G. E. MacDonald, and N. H. Peck. 1970. The potentiometric determination of nitrate and chloride in plant tissue. New York's Food Life Sci. Bull. No. 3:1-7.

Chagan, I., and K. Ushida. 2004. Detection of methanogens and proteolytic bacteria from a single cell of rumen ciliate protozoa. J. Gen. Appl. Microbiol. 38:203-212.

Charmley, E., S. R. O. Williams, P. J. Moate, R. S. Hegarty, R. M. Herd, V. H. Oddy, P. Reyenga, K. M. Staunton, A. Anderson, and M. C. Hannah. 2016. A universal equation to predict methane production of forage-fed cattle in Australia. Anim. Prod. Sci. 56:169-180. https://doi.org/10.1071/AN15365.

Couvreur, S., C. Hurtaud, C. Lopez, L. DeLaby, and J. L. Peyraud. 2006. The linear relationship between the proportion of fresh grass in the cow diet, milk fatty acid composition, and butter properties. J. Dairy Sci. 89:1956-1969. https://doi.org/10.3168/jds.S0022 -0302(06)72263-9.

Dairy One. 2019. Analytical Procedures. Accessed Oct. 7, 2019 https:// dairyone.com/download/forage-forage-lab-analytical -procedures/.

Deighton, M. H., S. R. O. Williams, M. C. Hannah, R. J. Eckard, T. M. Boland, W. J. Wales, and P. J. Moate. 2014. A modified sulphur hexafluoride tracer technique enables accurate determination of enteric methane emissions from ruminants. Anim. Feed Sci. Technol. 197:47-63. https://doi.org/10.1016/j.anifeedsci.2014 .08 .003 .

Dharma, S., W. Shafron, and M. Oliver. 2012. Australian dairy farm technology and management practices 2010-11. Australian Government Department of Agriculture, Fisheries and Forestry-Australian Bureau of Agricultural and Resource Economics and Sciences (ABARES): Canberra. Accessed Mar. 26, 2015. http://data .daff.gov.au/data/warehouse/9aab/9aabf/2012/adftm9aabf 006/ AustDairyFarmTechManagPrac_v1.0.0.pdf.

Doreau, M., L. Bamière, S. Pellerin, M. Lherm, and M. Benoit. 2014 Mitigation of enteric methane for French cattle: Potential extent and cost of selected actions. Anim. Prod. Sci. 54:1417-1422. https: //doi.org/10.1071/AN14207.

Fievez, V., E. Colman, J. M. Castro-Montoya, I. Stefanov, and B. Vlaeminck. 2012. Milk odd- and branched-chain fatty acids as biomarkers of rumen function-An update. Anim. Feed Sci. Technol. 172:51-65. https://doi.org/10.1016/j.anifeedsci.2011.12.008.

Geishauser, T. 1993. An instrument for collection and transfer of ruminal fluid and for administration of water soluble drugs in adult cattle. Bov. Pract. 27:38-41

Gerber, P. J., H. Steinfeld, B. Henderson, A. Mottet, C. Opio, J. Dijkman, A. Falcucci, and G. Tempio. 2013. Tackling Climate Change Through Livestock-A Global Assessment of Emissions and Mitigation Opportunities. Food Agric. Org. United Nations (FAO), Rome, Italy.

Greenwood, J. S., M. J. Auldist, L. C. Marett, M. C. Hannah, J. L. Jacobs, and W. J. Wales. 2014. Ruminal pH and whole-tract digestibility in dairy cows consuming fresh cut herbage plus concentrates and conserved forage fed either separately or as a partial mixed ration. Anim. Prod. Sci. 54:1056-1063. https://doi.org/10 $.1071 / \mathrm{AN} 12406$. 
Guan, H., K. M. Wittenberg, K. H. Ominski, and D. O. Krause. 2006. Efficacy of ionophores in cattle diets for mitigation of enteric methane. J. Anim. Sci. 84:1896-1906. https://doi.org/10.2527/jas .2005-652.

Harville, D. A. 1974. Nearly optimal allocation of experimental units using observed covariate values. Technometrics 16:589-599. https: //doi.org/10.1080/00401706.1974.10489242.

Haug, A., A. T. Hostmark, and O. M. Harstard. 2007. Bovine milk in human nutrition-A review. Lipids Health Dis. 6:25. https://doi .org/10.1186/1476-511X-6-25.

Hegarty, R. S. 1999. Reducing rumen methane emissions through elimination of rumen protozoa. Aust. J. Agric. Res. 50:1321-1327. https://doi.org/10.1071/AR99008.

International Dairy Federation. 1987. Milk: Determination of fat content-Rose Gottlieb gravimetric method (reference method). Pages 11-15 in International Dairy Federation Standard. Int. Dairy Fed., Brussels, Belgium.

Klop, G., J. Dijkstra, K. Dieho, W. H. Hendricks, and A. Bannink. 2017. Enteric methane production in lactating dairy cows with continuous feeding of essential oils or rotational feeding of essential oils and lauric acid. J. Dairy Sci. 100:3563-3575. https://doi.org/ 10.3168/jds.2016-12033.

Knapp, J. R., G. L. Laur, P. A. Vadas, W. P. Weiss, and J. M. Tricarico. 2014. Invited review: Enteric methane in dairy cattle production: Quantifying the opportunities and impact of reducing emissions. J. Dairy Sci. 97:3231-3261. https://doi.org/10.3168/jds 2013-7234.

Kolver, E. S., and L. D. Muller. 1998. Performance and nutrient intake of high producing Holstein cows consuming pasture or a total mixed ration. J. Dairy Sci. 81:1403-1411. https://doi.org/10.3168/ jds.S0022-0302(98)75704-2.

Kreuzer, M., M. Kirchgessner, and H. L. Muller. 1986. Methodik und Anwendung der Defaunierung bein wachsenden Wiedekauer. J. Vet. Med. A Physiol. Pathol. Clin. Med. 33:721-745. https://doi .org/10.1111/j.1439-0442.1986.tb00586.x.

Lana, R. P., J. B. Russell, and M. E. Van Amburgh. 1998. The role of $\mathrm{pH}$ in regulating ruminal methane and ammonia production. J. Anim. Sci. 76:2190-2196. https://doi.org/10.2527/1998.7682190x.

Leddin, C. M., C. R. Stockdale, J. Hill, J. W. Heard, and P. T. Doyle. 2010. Increasing amounts of crushed wheat fed with Persian clover herbage reduced ruminal $\mathrm{pH}$ and dietary fibre digestibility in lactating dairy cows. Anim. Prod. Sci. 50:837-846. https://doi.org/ 10.1071/AN09157.

Martin, C., D. P. Morgavi, and M. Doreau. 2010. Methane mitigation in ruminants: From microbe to the farm scale. Animal 4:351-365. https://doi.org/10.1017/S1751731109990620.

Moate, P. J., W. Chalupa, R. C. Boston, and I. J. Lean. 2007. Milk fatty acids. I. Variation in the concentration of individual fatty acids in bovine milk. J. Dairy Sci. 90:4730-4739. https://doi.org/ $10.3168 /$ jds.2007-0225.

Moate, P. J., M. H. Deighton, S. R. O. Williams, J. E. Pryce, B. J. Hayes, J. L. Jacobs, R. J. Eckard, M. C. Hannah, and W. J. Wales. 2016. Reducing the carbon footprint of Australian milk production by mitigation of enteric methane emissions. Anim. Prod. Sci. 56:1017-1034. https://doi.org/10.1071/AN15222.

Moate, P. J., J. L. Jacobs, M. C. Hannah, G. L. Morris, K. A. Beauchemin, P. S. Alvarez-Hess, R. J. Eckard, Z. Liu, S. Rochfort, W. J. Wales, and S. R. O. Williams. 2018. Adaptation responses in milk fat yield and methane emissions of dairy cows when wheat was included in their diet for 16 weeks. J. Dairy Sci. 101:7117-7132. https://doi.org/10.3168/jds.2017-14334.

Moate, P. J., S. R. O. Williams, M. H. Deighton, M. C. Hannah, J. L. Jacobs, and W. J. Wales. 2017a. Can concentrations of trans octadecenoic acids in milk fat be used to predict methane yields of dairy cows? Anim. Prod. Sci. 57:1465-1470. https://doi.org/10 .1071/AN16477.

Moate, P. J., S. R. O. Williams, M. H. Deighton, M. C. Hannah, B. E. Ribaux, J. L. G. L. Morris, J. L. Jacobs, J. Hill, and W. J. Wales. 2019. Effect of feeding wheat or corn and of rumen fistulation on milk production and methane emissions of dairy cows. Anim. Prod. Sci. 59:891-905. https://doi.org/10.1071/AN17433.
Moate, P. J., S. R. O. Williams, J. L. Jacobs, M. C. Hannah, K. A. Beauchemin, R. J. Eckard, and W. J. Wales. 2017b. Wheat is more potent than corn or barley for dietary mitigation of enteric methane emissions from dairy cows. J. Dairy Sci. 100:7139-7153. https: //doi.org/10.3168/jds.2016-12482.

Moate, P. J., S. R. O. Williams, V. A. Torok, M. C. Hannah, B. E. Ribaux, M. H. Tavendale, R. J. Eckard, J. L. Jacobs, M. J. Auldist, and W. J. Wales. 2014. Grape marc reduces methane emissions when fed to dairy cows. J. Dairy Sci. 97:5073-5087. https://doi .org/10.3168/jds.2013-7588.

Mohammed, N., N. Ajisaka, Z. A. Lila, K. Hara, K. Mikuni, K. Hara, S. Kanda, and H. Itabashi. 2004. Effect of Japanese horseradish oil on methane production and ruminal fermentation in vitro and in steers. J. Anim. Sci. 82:1839-1846. https://doi.org/10.2527/2004 $.8261839 x$.

National Health and Medical Research Council. 2004. Australian Code of Practice for the Care and Use of Animals for Scientific Purposes. 7th ed. Natl. Health Med. Res. Counc., Canberra, Australia.

NRC. 2001. Nutrient Requirements of Dairy Cattle. 7th rev. ed. Natl. Acad. Press, Washington, DC.

Ogimoto, K., and S. Imai. 1981. Atlas of Rumen Microbiology. Japan Sci. Soc. Press, Tokyo, Japan.

Plaizier, J. C., D. O. Krause, G. N. Gozho, and B. W. McBride. 2008. Subacute ruminal acidosis in dairy cows: The physiological causes, incidence and consequences. Vet. J. 176:21-31. https://doi.org/10 $.1016 / j . t v j 1.2007 .12 .016$.

Robaina, A. C., C. Grainger, P. J. Moate, J. Taylor, and J. Stewart. 1998. Responses to grain feeding by grazing dairy cows. Aust. J. Exp. Agric. 38:541-549. https://doi.org/10.1071/EA97087.

Roe, M. B., and C. J. Sniffen. 1990. Techniques for measuring protein fractions in feedstuffs. Pages 81-88 in Proc. Cornell Nutr. Conf. Rochester, NY. Cornell University, Ithaca, NY.

Rugoho, I., C. J. P. Gourley, and M. C. Hannah. 2017. Nutritive characteristics, mineral concentrations and dietary cation-anion difference of feeds used within grazing-based dairy farms in Australia. Anim. Prod. Sci. 57:858-876. https://doi.org/10.1071/AN15761.

Sauvant, D., S. Giger-Reverdin, A. Serment, and L. Broudiscou. 2011. Influences des régimes et de leur fermentation dans le rumen sur la production de méthane par les ruminants. INRA Prod. Anim. 24:433-446.

Sirois, P. K., M. J. Reuter, C. M. Laughlin, and P. J. Lockwood. 1994. A method for determining macro and micro elements in forages and feeds by inductively coupled plasma atomic emission spectrometry. Spectroscopist 3:6-9.

Slover, H. T., and E. Lanza. 1979. Quantitative analysis of food fatty acids by capillary gas chromatography. J. Am. Oil Chem. Soc. 56:933-934. https://doi.org/10.1007/BF02674138.

Smith, D. 1969. Removing and Analyzing Total Non-Structural Carbohydrates from Plant Tissue. Wisconsin Agric. Exp. Stn. Res. Rep. 41. Wisconsin Agric. Exp. Stn., Madison.

Stockdale, C. R. 2004. Effects of level of feeding concentrates during early lactation on the yield and composition of milk from grazing dairy cows with varying body condition score at calving. Aust. J. Exp. Agric. 44:1-9. https://doi.org/10.1071/EA03021.

Stockdale, C. R., G. P. Walker, W. J. Wales, D. E. Dalley, A. Birkett, Z. Shen, and P. T. Doyle. 2003. Influence of pasture and concentrates in the diet of grazing dairy cows on the fatty acid composition of milk. J. Dairy Res. 70:267-276. https://doi.org/10.1017/ s0022029903006009.

Supelco Inc. 1975. GC separation of VFA C2-C5. Technical Bulletin 749D. Supelco Inc., Bellefonte, PA.

Tyrrell, H. F., P. W. Moe, and W. P. Flatt. 1970. Influence of excess protein intake on energy metabolism of the dairy cow. Pages 69-72 in Energy Metabolism of Farm Animals. 5th ed. A. Schurch and C. Wenks, ed. EAAP Publ. No. 13. Juris Verlag, Zurich, Switzerland.

Tyrrell, H. F., and J. T. Reid. 1965. Prediction of the energy value of cow's milk. J. Dairy Sci. 48:1215-1223. https://doi.org/10.3168/ jds.S0022-0302(65)88430-2.

Van Soest, P. J., J. B. Robertson, and B. A. Lewis. 1991. Symposium: Carbohydrate methodology, metabolism, and nutritional implications in dairy cattle. Methods for dietary fiber, neutral deter- 
gent fiber, and nonstarch polysaccharides in relation to animal nutrition. J. Dairy Sci. 74:3583-3597. https://doi.org/10.3168/jds .S0022-0302(91)78551-2.

International, V. S. N. 2016. Genstat 18 software. VSN International, Hemel Hempstead, UK.

Wales, W. J., E. S. Kolver, A. R. Egan, and J. R. Roche. 2009. Effects of strain of Holstein-Friesian and concentrate supplementation on the fatty acid composition of milk fat of dairy cows grazing pasture in early lactation. J. Dairy Sci. 92:247-255. https://doi.org/ 10.3168/jds.2008-1386.

Walker, G. P., C. R. Stockdale, W. J. Wales, P. T. Doyle, and D. W. Dellow. 2001. Effect of level of grain supplementation on milk production responses of dairy cows in mid-late lactation when grazing irrigated pastures high in paspalum (Paspalum dilatatum Poir.). Aust. J. Exp. Agric. 41:1-11. https://doi.org/10.1071/EA00076.

Weimer, P. J., D. M. Stevenson, H. C. Mantovani, and S. L. C. Man. 2010. Host specificity of the ruminal bacterial community in the dairy cow following near-total exchange of ruminal contents. J. Dairy Sci. 93:5902-5912. https://doi.org/10.3168/jds.2010-3500.

Wilkinson, J. M. 2011. Re-defining efficiency of feed use by livestock. Animal 5:1014-1022. https://doi.org/10.1017/S175173111100005X.

Williams, S. R. O., T. Clarke, M. C. Hannah, L. C. Marett, P. J. Moate, M. J. Auldist, and W. J. Wales. 2013. Energy partitioning in herbage fed dairy cows offered supplementary grain during an extended lactation. J. Dairy Sci. 96:484-494. https://doi.org/10 $.3168 /$ jds.2012-5787.

Williams, S. R. O., P. J. Moate, M. C. Hannah, B. E. Ribaux, W. J. Wales, and R. J. Eckard. 2011. Background matters with the $\mathrm{SF}_{6}$ tracer method for estimating enteric methane emissions from dairy cows: A critical evaluation of the $\mathrm{SF}_{6}$ procedure. Anim. Feed Sci. Technol. 170:265-276. https://doi.org/10.1016/j.anifeedsci.2011 .08 .013 .

Yang, W. Z., K. A. Beauchemin, and L. M. Rode. 2001. Effects of grain processing, forage to concentrate ratio, and forage particle size on rumen $\mathrm{pH}$ and digestion by dairy cows. J. Dairy Sci. 84:2203-2216. https://doi.org/10.3168/jds.S0022-0302(01)74667-X.

\section{ORCIDS}

P. J. Moate ㄴ https://orcid.org/0000-0003-4598-2047

M. H. Deighton ๑ https://orcid.org/0000-0003-0663-738X

S. R. O. Williams @ https://orcid.org/0000-0003-1321-6487 